\title{
KARAKTERISTIK STRUKTUR DAN SIFAT KIMIA PRODUK BIOGENIK RAYAP SCHEDORHINOTERMES SPP DARI CAMPURAN LIMBAH KERTAS KORAN DENGAN LIMBAH PENGOLAHAN TAHU
}

\author{
Structure and Chemical Properties of Biogenic Product Made of Newsprint Paper and Tofu Processing Wastes by \\ Termite Schedorhinotermes spp.
}

\author{
Andi Sri Rahayu Diza Lestari A ${ }^{凶}$, Musrizal Muin, Astuti Arif \\ Fakultas Kehutanan, Universitas Hasanuddin, Makassar \\ ${ }^{\bowtie}$ corresponding author: asrdlestari@unhas.ac.id
}

\begin{abstract}
Biological activity of termites consistently generates various biogenic products depend of the type of food sources. Furthermore, the biogenic product is believed to have an important role in the improvement of soil physical and chemical properties. The purpose of this study is to determine the structure and chemical properties of biogenic products resulted from the activity of termites Schedorhinotermes spp. using newsprint paper and tofu processing wastes as food sources. Newsprint paper waste was mixed with tofu processing wastes water at a different levels, i.e. $10 \%, 20 \%$, and $30 \%$ (w/v) for the objective of study. Each of the mixture with weight of 18,8 g equivalent to oven dry weight was then placed in the sample container unit size $6 \times 6 \mathrm{~cm}$, placed at about 3 $\mathrm{cm}$ underground with the indicated of termite Schedorhinotermes spp activity, and covered by PVC stopper. The testing unit were left in place for about 6 weeks to allow the termite attacks. The attacked sample unit were then analyzed for their structure and chemical properties including bulk density, aggregate fraction distribution, $\mathrm{pH}, \mathrm{C}$-organic content. The soil around the sample unit were took using a $7 \mathrm{~cm}$ diameter ground ring to be used as a reference or comparison with biogenic structures formed by termites. The result showed that the biogenic products have better structure and chemical compared to the its surrounding soil.
\end{abstract}

Keywords: Biogenic, Schedorhinotermes spp, newsprint paper waste, tofu processing waste

\section{A. PENDAHULUAN}

Rayap yang termasuk dalam ordo Isoptera hidup secara berkoloni. Dalam satu koloni rayap terdiri atas ratu, raja serta sekumpulan prajurit dan pekerja yang masingmasing memiliki tugas yang berbeda dan sangat penting bagi kelangsungan hidup koloninya (Tarumingkeng, 2004). Makanan utama rayap adalah selulosa dan hemiselulosa atau biasa disebut dengan holoselulosa. Kedua jenis senyawa ini merupakan komponen penyusun penting yang terdapat pada tumbuhan. Tumbuhan yang masih hidup maupun yang telah melalui proses pengolahan seperti kayu hasil tebang, kertas koran dan macam-macam kertas lainnya, sampai bahan bangunan yang semuanya mengandung holoselulosa sangat disukai oleh rayap.

Dalam ekosistem, rayap memiliki peranan penting sebagai dekomposer atau pengurai tumbuhan yang lapuk atau sudah mati menjadi unsur yang lebih sederhana sehingga dapat langsung terserap di dalam tanah (Astuti et al., 2010). Hasil penelitian sebelumnya yang dilakukan oleh Pardeshi dan Prusty (2010) menunjukkan bahwa rayap juga memiliki kelebihan lain seperti memelihara struktur tanah dengan memodifikasi karakteristik kimiawi tanah serta mampu memperbaiki sifat fisik tanah. Di alam, bahan organik bisa didapatkan dari tumbuhan dan produk turunannya. Sedangkan, dalam kehidupan manusia bahan organik juga bisa didapatkan dari berbagai sumber, termasuk pada limbah hasil pengolahan bahan makanan. Salah satu contoh limbah hasil pengolahan bahan makanan adalah limbah pengolahan tahu. Tahu yang merupakan produk hasil olahan kedelai sangat mudah dijumpai di Indonesia. Hal ini dikarenakan tahu merupakan salah satu makanan sumber protein yang cukup digemari oleh masyarakat Indonesia. Sementara, limbah dari pengolahan tahu ini sendiri cenderung memiliki nilai ekonomis rendah di mata masyarakat sehingga masih jarang dimanfaatkan. Selain sebagai bahan organik, hasil penelitian sebelumnya yang dilakukan oleh Sulistijani (1998) dalam Yulia (2004) menunjukkan bahwa limbah pengolahan tahu juga merupakan limbah yang memiliki kandungan selulosa yang disukai oleh rayap. Penelitian ini ditujukan untuk memanfaatkan jenis limbah pengolahan tahu yang dicampurkan limbah kertas koran sebagai sumber makanan rayap untuk produksi biogenik 


\section{B. METODE PENELITIAN}

Limbah kertas koran dan limbah cair pengolahan tahu dicampur dengan perbandingan 20\% (200 g kertas koran per $1000 \mathrm{ml}$ limbah pengolahan tahu) dan 30\% (300 $\mathrm{g}$ kertas koran per $1000 \mathrm{ml}$ limbah pengolahan tahu). Campuran tersebut dicabik dan dibiarkan hingga diperoleh bubur kertas berupa serat-serat limbah yang bercampur limbah pengolahan tahu. Bubur kertas kemudian diperas dan dimasukkan ke dalam plastik klip yang telah diberi label sesuai dengan komposisi atau campuran yang telah ditentukan.

Sampel uji (sebanyak 18,8 gram setara berat kering tanur untuk masing-masing perbandingan) dimasukkan ke dalam wadah kayu berukuran $6 \times 6\left(\mathrm{~cm}^{2}\right)$. Wadah kayu yang telah berisi sampel ditanam sedalam $3 \mathrm{~cm}$ di dalam tanah pada daerah yang memiliki aktivitas serangan rayap tinggi. Semua bagian atas unit pengujian ditutup dengan menggunakan stopper PVC ukuran 3 inci untuk membuat suasana gelap dan melindungi sampel uji. Unit pengujian dibiarkan di lapangan hingga tampak terdapat aktivitas rayap yang nyata pada sampel uji. Dalam penelitian ini, adanya aktivitas rayap ditunjukkan setelah 6 minggu. Selanjutnya, unit sampel berupa wadah kayu beserta penutupnya diambil kemudian dibawa ke laboratorium untuk dilakukan penentuan struktur biogenik dan pengujian kandungan kimianya. Tanah yang berada di sekitar unit sampel diambil menggunakan ring tanah yang berdiameter $7 \mathrm{~cm}$ untuk digunakan sebagai referensi atau pembanding terhadap struktur biogenik yang dibentuk oleh rayap.

Struktur biogenik yang diamati adalah kerapatan (bulk density) dan distribusi fraksi agregat. Penentuan kerapatan dan distribusi fraksi agregat dilakukan berdasarkan prosedur yang dikemukakan oleh Kemper dan Rousenaou (1986) dalam Decaëns et al. (2001). Sedangkan, pengujian sifat kimia produk biogenik dilakukan dengan menentukan nilai $\mathrm{pH}$ dan kadar Corganik pada produk biogenik. Nilai pH ditentukan dengan cara meletakkan $\mathrm{pH}$-meter ke dalam campuran produk aktivator rayap dengan air menggunakan perbandingan 1 : 2,5. Penentuan kadar C-organik dilakukan berdasarkan metode Walkley dan Black dalam Sunanto (2010). Datadata yang diperoleh dalam penelitian ini dianalisis secara deskriptif kualitatif dan kuantitatif.

\section{HASIL DAN PEMBAHASAN}

\section{Kerapatan (bulk density)}

Hasil penelitian menunjukkan adanya penurunan nilai kerapatan yang sangat tinggi antara sebelum pengumpanan dan setelah pengumpanan seperti ditunjukkan pada Tabel 1. Hal ini disebabkan karena adanya aktivitas proses biologi rayap Schedorhinotermes spp. Pada sampel uji dalam wadah menyebabkan terjadinya pengurangan jumlah dan kepadatan pada sampel uji. Sementara itu, kerapatan struktur biogenik yang dihasilkan oleh rayap cenderung lebih rendah dibandingkan dengan kerapatan pada tanah sekitar sampel uji di lapangan. Dari hasil yang telah didapatkan tersebut dapat diketahui bahwa produk biogenik rayap memiliki kerapatan tanah yang lebih menguntungkan bagi perakaran tanaman dibandingkan dengan tanah di sekitarnya. Russel (1977) dalam Rusdiana (2000) mengemukakan bahwa kerapatan tanah yang tinggi akan menyebabkan terjadinya penurunan ruang pori makro dalam tanah yang akhirnya menghambat penetrasi akar.

Tabel 1. Kerapatan (bulk density) sampel uji dan struktur biogenik yang dihasilkan oleh rayap Schedorhinotermes spp. dari campuran limbah pengolahan tahu dengan limbah kertas koran

\begin{tabular}{lccc}
\hline Sampel Uji & $\begin{array}{c}\text { Kerapatan } \\
\text { Sebelum } \\
\text { Pengumpanan } \\
\left(\mathrm{g} \mathrm{cm}^{-3}\right)\end{array}$ & $\begin{array}{c}\text { Kerapatan } \\
\text { Setelah } \\
\text { Pengumpanan } \\
\left(\mathrm{g} \mathrm{cm}^{-3}\right)\end{array}$ & Referensi* \\
\hline $20 \%$ & 1,32 & 0,25 & 0,65 \\
$30 \%$ & 1,26 & 0,34 & \\
\hline
\end{tabular}

Keterangan: *top soil sekitar sampel uji di lapangan

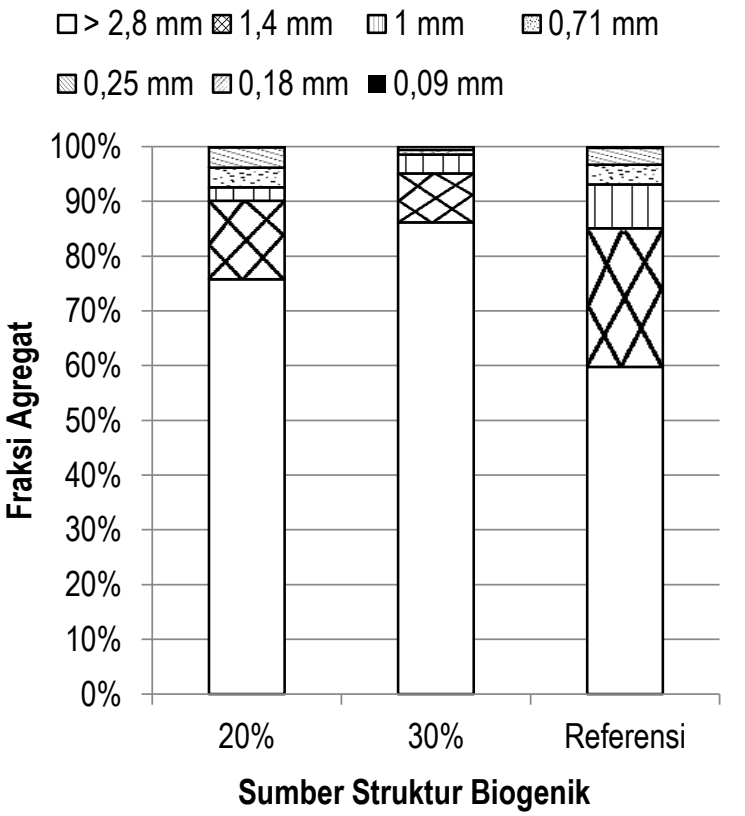

Gambar 1. Distribusi fraksi agregat struktur biogenik yang dihasilkan oleh rayap Schedorhinotermes spp.

\section{Distribusi Fraksi Agregat}

Hasil analisis terhadap fraksi-fraksi agregat dari produk biogenik yang dihasilkan dalam penelitian ini menunjukkan bahwa ukuran partikel agregat pada seluruh sampel hasil proses biologis rayap lebih besar dibandingkan dengan tanah di sekitar lokasi sampel uji (Gambar 1). Keadaan tersebut disebabkan karena perilaku rayap dalam mengolah tanah dengan mengangkut dan merekatkan partikel tanah menggunakan saliva membentuk sebuah struktur biogenik yang secara 
tidak langsung menyebabkan adanya perubahan pada tekstur tanah yang telah diolah. Hal ini sejalan dengan yang dikemukakan oleh de Broyn et al. (1990) dalam Decaëns (2001) bahwa rayap merekatkan partikel-partikel tanah menggunakan sekresi saliva dalam membangun konstruksi dinding pada sarangnya. Kohnke (1968) dalam Riyadi (2002) mengemukakan bahwa besarnya ukuran partikel agregat pada tanah menunjukkan bahwa tanah tersebut memiliki kapasitas mengikat air dan melewatkan air yang baik sehingga membantu dalam pengendalian limpasan permukaan dan erosi.

\section{Tingkat Kemasaman (pH)}

Data hasil penelitian seperti ditunjukkan pada Tabel 2 memberikan indikasi bahwa kadar $\mathrm{pH}$ produk biogenik baik bagian luar maupun dalam yang dihasilkan oleh rayap Schedorhinotermes spp. pada sampel uji cenderung lebih tinggi dibandingkan dengan nilai $\mathrm{pH}$ pada tanah di sekitarnya. Dari hasil yang telah didapatkan tersebut dapat diketahui bahwa produk biogenik yang dihasilkan oleh rayap memiliki tingkat kesuburan yang lebih baik dibandingkan dengan tanah di sekitarnya. Hal ini sesuai dengan yang dikemukakan oleh Hardjowigeno (1987) bahwa pada umumnya akar tanaman mampu menyerap unsur hara dengan baik pada tanah yang memiliki $\mathrm{pH}$ netral. Selain itu, mikroorganisme seperti bakteri pengikat nitrogen dan bakteri nitrifikasi hanya dapat berkembang baik pada tanah yang memiliki $\mathrm{pH}>5,5$. Sementara pada tanah dengan tingkat kemasaman tinggi ditemukan banyak ion-ion Al yang merupakan racun pada akar tanaman.

Tabel 2. Nilai pH produk biogenik yang dihasilkan oleh rayap Schedorhinotermes spp. dari campuran limbah pengolahan tahu dengan limbah kertas Koran

\begin{tabular}{lrrc}
\hline \multirow{2}{*}{ Sampel Uji } & \multicolumn{3}{c}{ Ph } \\
\cline { 2 - 4 } & Luar & Dalam & Referensi $^{*}$ \\
\hline $20 \%$ & 5,20 & 5,15 & \\
$30 \%$ & 7,13 & 6,10 & 5,33 \\
Rata-rata & 6,16 & 5,62 & \\
\hline
\end{tabular}

Keterangan: *top soil sekitar sampel uji di lapangan

\section{Kadar C-Organik}

Hasil penelitian menunjukkan bahwa produk biogenik yang dihasilkan oleh rayap Schedorhinotermes spp. baik pada bagian luar maupun dalam, memiliki konsentrasi kadar C-organik lebih tinggi dibandingkan dengan tanah sekitar sampel uji di lapangan (Tabel 3). Hasil yang diperoleh sejalan dengan penelitian yang dilakukan oleh Decaëns et al. (2001) yang mengemukakan bahwa dinding-dinding sarang yang dibuat oleh rayap kaya akan kadar C-organik jika dibandingkan dengan tanah di sekitar sarang sebagai kontrol. Selain itu, berdasarkan penelitian yang dilakukan oleh Jiménez and Decaëns (2006), dapat diketahui bahwa bahan organik dalam jumlah yang besar didapatkan dari kotoran dan ekskresi saliva rayap yang merupakan komponen utama dalam membangun sarang. Mulyani (1997) dalam Riyadi (2002) mengemukakan manfaat dari tingginya bahan organik dalam tanah adalah sebagai sumber makanan dan energi bagi mikroorganisme sehingga membantu peningkatan unsur hara lainnya dalam tanah.

Tabel 3. Kadar C-organik yang terkandung dalam produk biogenik yang dihasilkan oleh rayap Schedorhinotermes spp. dari campuran limbah pengolahan tahu dengan limbah kertas koran

\begin{tabular}{lccc}
\hline \multirow{2}{*}{ Sampel Uji } & \multicolumn{3}{c}{ C-organik (\%) } \\
\cline { 2 - 4 } & Luar & Dalam & Referensi $^{*}$ \\
\hline $20 \%$ & 3,44 & 2,73 & \\
$30 \%$ & 4,20 & 3,59 & 2,54 \\
Rata-rata & 3,82 & 3,16 & \\
\hline
\end{tabular}

Keterangan: *top soil sekitar sampel uji di lapangan

\section{KESIMPULAN}

Berdasarkan uraian dari hasil penelitian ini, maka dapat ditarik kesimpulan bahwa produk biogenik yang dihasilkan oleh rayap Schedorhinotermes spp. dari campuran limbah pengolahan tahu dengan limbah kertas koran memiliki karakteristik struktur biogenik berupa kerapatan yang lebih rendah serta fraksi agregat yang lebih besar jika dibandingkan dengan tanah disekitarnya. Sementara itu, kandungan kimia bahan dari produk biogenik memiliki nilai pH dan kadar C-organik lebih baik dibandingkan tanah di sekitarnya.

\section{DAFTAR PUSTAKA}

Astuti, Taskirawati, I., \& Affandi. (2010). Morphometric analysis of Coptotermes sp. population from two different nests. Jurnal Perennial, 6(2): $60-69$

Decaëns, T., Galvis, J. H., \& Amésquita, E. (2001). Properties of the structures created by ecosystem engineers on the soil surface of a Colombian savanna. Compte rendus de l'Academie des sciences, serie III 324 (5): 465 - 478

Hardjowigeno, S. (1989). IImu Tanah. Jakarta, Indonesia: Mediyatama sarana perkasa.

Jimènez, T, \& Decaëns. T. (2006). Chemical variation in the biostructures produced by soil ecosystem engineers: Examples from the neotropical savannas. European Journal of Soil Biology 42(1): 92 - 102

Yulia, N. (2004). Pemanfaatan Tepung Ampas Tahu dalam Pembuatan Minuman Fermentasi Probiotik dengan Starter Lactobacillus casei. Skripsi, Fakultas Pertanian. Bogor: Institut Pertanian Bogor

Pardeshi, M., \& Prusty, K. A. B. (2010). Termites as ecosystem engineers and potensials for soil restoration. Current science 99(1): 11

Riyadi, A. (2002). Kajian Teknologi irigasi bawah tanah dengan pengelolaan lahan pasir: Studi Kasus di Desa Karangwuni, Kulon Progo, Yogyakarta. Program Pascasarjana Institut Pertanian Bogor. Bogor

Rusdiana, O., Fakuara, Y., Kusmana, C., \& Hidayat, Y. (2000.) Respon pertumbuhan akar tanaman sengon (Paraserianthes 
falcataria) terhadap kepadatan dan kandungan air tanah podsolik merah kuning. Jurnal Manajemen Hutan Tropika 6(2): $43-53$

Sunanto, A. (2010). Distribusi Bentuk C-Organik pada Vegetasi yang Berbeda. Skripsi. Fakultas Pertanian Institut Pertanian Bogor.
Tarumingkeng, R. C. (2004). Biologi dan pengendalian rayap ramah lingkungan di Indonesia. Fakultas Kehutanan Institut Pertanian Bogor. Bogor. 